\title{
A Triatoma maculata (HEMIPTERA, REDUVIIDAE, TRIATOMINAE) POPULATION FROM RORAIMA, AMAZON REGION, BRAZIL, HAS SOME BIONOMIC CHARACTERISTICS OF A POTENTIAL CHAGAS DISEASE VECTOR
}

\author{
José Francisco LUITGARDS-MOURA(1), André Barbosa VARGAS(2,5), Carlos Eduardo ALMEIDA(2), Gleidson MAGNO-ESPERANÇA(2,3), \\ Ronildo AGAPITO-SOUZA(2,3), Elaine FOLLY-RAMOS(2), Jane COSTA(2), Pantelis TSOURIS (1,6) \& Maria Goreti ROSA-FREITAS(1,4)
}

\begin{abstract}
SUMMARY
Even though Chagas disease is rare in the Brazilian Amazon, the conditions for the establishment of domiciliated cycles prevail in many areas where triatomines are of frequent occurrence. In Roraima, a previous serological and entomological survey in three agricultural settlements showed the existence of all transmission cycle elements, i.e., individuals infected by Trypanosoma cruzi, triatomine species previously found harboring T. cruzi in the broader Amazon region of neighboring countries and, domicile/ peridomicile conditions favorable to triatomine colonization. Triatoma maculata was the most frequent species, found in chicken houses in the peridomicile and sporadically within residences. Aiming to investigate the possibility of T. maculata to possess the potentiality to transmit $T$. cruzi in the area, bionomic characteristics were studied under laboratory conditions. These were feeding frequency, time for defecation after a blood meal, time elapsed in voluntary fasting pre- and pos-ecdysis, moulting time periods, pre-oviposition and oviposition periods and index of oviposition, incubation period, egg viability, longevity and mortality rate. Results show that the Passarão population of T. maculata should be considered a potential vector of $T$. cruzi since it shows a capacity to infest artificial ecotopes in the peridomicile, to carry out large number of meals during the nymphal cycle, to have a relatively short developmental cycle capable of producing 2.9 generations/year, to blood source eclecticism, to defecate immediately after the blood meal while still on the host and to the fact that has been previously found naturally infected by T.cruzi.
\end{abstract}

KEYWORDS: Triatoma maculata; Chagas disease; Amazon; Roraima; Brazil; Bionomic studies.

\section{INTRODUCTION}

Even though Chagas disease is rare in the Amazon region, the conditions for the establishment of domiciliated cycles prevail in many areas. Triatomine species potential vectors of Chagas disease are of frequent occurrence in those areas. In Roraima, a serological and entomological survey in three agricultural settlements and blood donor candidates showed the existence of all transmission cycle components (LUITGARDS-MOURA, 2001; LUITGARDS-MOURA et al., 2005). These transmission cycle components were: individuals infected by Trypanosoma cruzi, triatomine specimens of potential vector species in the peridomicile (Rhodnius robustus, Triatoma maculata, Panstrongylus geniculatus and Rhodnius pictipes) and, domicile conditions for triatomine colonization. All species were found away from human dwellings with lower infestation and density indices except for T. maculata. Triatoma maculata was the most numerous species found in chicken houses in the peridomicile, presenting a peridomiciliary infestation index of 16.7 (number of annexes with triatomines/number of annexes x 100, WHO, 2002) and a crowding index of 12500 (number of triatomines captured/number of houses $\mathrm{x}$ 100, WHO, 2002) represented by the peridomiciliary collection of 375 specimens in chicken annexes of only three houses (out of 48 investigated houses) when 125 triatomines per chicken house were found living in chicken nests, underneath cardboard boxes, wood pieces, stones and bricks (LUITGARDS-MOURA et al., 2005). This peridomiciliation is of particular interest in Chagas disease transmission. The adaptation to the human dwelling of vector species in deforested areas is thought to be linked to the recent findings of $T$. cruzi in human populations in the Amazon (COURA, 1990; WALSH et al., 1993) where the low frequency of human autochtonous cases of Chagas disease contrasts with the high infection indices found in reservoirs and vectors (VALENTE \& VALENTE, 1993). The present study was conducted in order to observe whether this T. maculata population shared other biological traits, than the observed colonization of the human

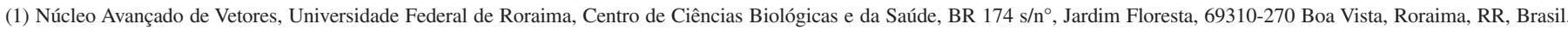

(2) Núcleo de Informatização, Coleção Entomológica, Departamento de Entomologia, Instituto Oswaldo Cruz, Rio de Janeiro, RJ, Brasil.

(3) Museu de Ciências, Centro Universitário de Barra Mansa, UBM.

(4) Laboratório de Transmissão de Hematozoários, Departamento de Entomologia, Instituto Oswaldo Cruz, Rio de Janeiro, RJ, Brasil.

(5) Programa de Pós-Graduação em Biologia Animal, Universidade Federal Rural do Rio de Janeiro, UFRRJ.

(6)Freitas-Tsouris Consultants, PO Box 117, Spata-Attikis, 19004, Greece.

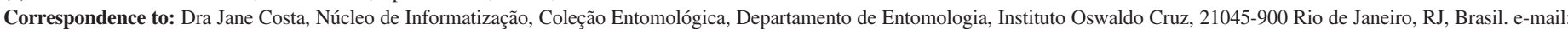
jcosta@ioc.fiocruz.br 


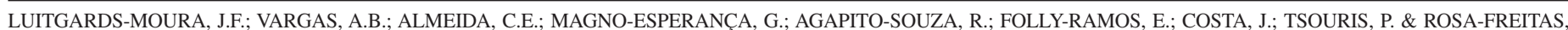
M.G. - A Triatoma maculata (Hemiptera, Reduviidae, Triatominae) population from Roraima, Amazon region, Brazil, has some bionomic characteristics of a potential Chagas disease vector. Rev. Inst. Med. trop. S. Paulo, 47(3): 131-137, 2005.

environment, which would point it out as being a potential Chagas disease vector in the area. Among those traits, triatomine feeding frequency and speed of defecation after a blood meal is of great importance for T. cruzi transmission (DIAS, 1956; COSTA \& JURBERG, 1990; ALMEIDA et al., 2003). Notwithstanding the fact that triatomine infection was not observed, the triatomine species collected were previously found harboring $T$. cruzi in natural habitats in the broader Amazon region of neighboring countries, some of which actively involved in Chagas disease transmission. $R$. robustus is the main sylvatic cycle vector in Venezuela (CARCAVALLO et al., 1975; OTERO et al., 1975). In the Venezuelan endemic rural area houses were also found infested with $T$. maculata, P. geniculatus, $R$. robustus, $R$. pictipes and the main domiciliated vector $R$. prolixus (TONN et al., 1976; TONN et al., 1978; ZELEDON \& RABINOVICH, 1981). In the Guyanas, Venezuela and Colombia T. maculata, $R$. pictipes, $P$. geniculatus were found naturally infected (DIAS \& TORREALBA, 1936; DIAS, 1952). R. robustus was present in those areas but not infected (DIAS, 1952). In Venezuela, T. maculata was found naturally infected by T. cruzi and T. rangeli (PIFANO, 1973; SIFONTES, 1976). In the Brazilian Amazon P. geniculatus, $R$. pictipes and $R$. robustus, but not T. maculata, were found infected by $T$. cruzi or T.cruzi-like (ALMEIDA, 1971; BARRET, 1988; COURA et al., 1994; COURA et al., 1999; VALENTE et al., 1999). In Roraima there are no reports in the literature of naturally infected triatomines. Specimens of Rhodnius, Panstrongylus and Eratyrus were collected in the Maracá Ecological Station (RAFAEL \& PY-DANIEL, 1989). T. maculata was previously described in Roraima (MILES et al., 1981; PESSOA, 1988).

The success of a triatomine species as vector depends among other variables on the susceptibility to infection, the frequency of blood meals, the characteristic of defecating during or shortly after the blood meal and the starvation resistance (DIAS, 1956; PELLEGRINO, 1952; PERLOWAGORA-SZUMLEWICZ, 1954; 1969).

This work is part of the first epidemiological study on Chagas disease conducted in agricultural settlements in Roraima (LUITGARDS-MOURA, 2001; LUITGARDS-MOURA et al., 2005). Triatoma maculata was the most numerous species found in chicken houses in the peridomicile. The experiments conducted aim to investigate some bionomic characteristics of $T$. maculata that may account for the potential participation of the species as vector in the studied area. Variables examined were feeding frequency, time for defecation after a blood meal, time elapsed in voluntary fasting preand pos-ecdysis, moulting time periods, pre-oviposition and oviposition periods and index of oviposition, egg incubation period, egg viability, longevity and mortality rates.

\section{MATERIALS AND METHODS}

A colony was initiated with 46 nymphs of T. maculata collected during August-September 2000 at the Passarão Project (area comprised from $03^{\circ} 05^{\prime}$ to $03^{\circ} 20^{\prime} \mathrm{N}$ and $60^{\circ} 35^{\prime}$ to $60^{\circ} 43^{\prime} \mathrm{W}$ ), Roraima, Brazil. Specimens were transported to the triatomine insectarium laboratories (Department of Entomology, FIOCRUZ, Rio de Janeiro) reared at room temperature (temperature mean $27.6^{\circ} \mathrm{C}$, min. 21.5 ${ }^{\circ} \mathrm{C}$, max. $32{ }^{\circ} \mathrm{C}$ and humidity mean $77.5 \%$, min. $52 \%$, max. 96\%). Feeding was performed ad libitum weekly on mice Mus musculus until imaginal ecdysis. The experiments were carried out in the F1 of these wild-caught nymphs kept in the same environmental conditions as the parental generation.

Forty same-day ecloded nymphs were placed individually in plastic jars (4 $\mathrm{cm}$ square base, $9 \mathrm{~cm}$ height) with a piece of folded filter paper (Klabin 80) as substrate and a perforated plastic cover, for daily observation of bionomic parameters as follows, using techniques formerly described (ALMEIDA, 2000).

1. Time for defecation after a blood meal and number of blood meals: Once a week insects were individually transferred to circular plastic arenas $(\varnothing 10 \mathrm{~cm}, 15 \mathrm{~cm}$ height, with a piece of filter paper as substrate) together with a ketamin anaesthetized mouse $(0.35 \mathrm{mg} / \mathrm{kg}$ of body weight dose). The rate for the mean number of accepted blood meals/mean number of offers (in weeks) was calculated individually for each nymphal stage. The elapsed time between the end of feeding and defecation was registered. The end of the blood meal was registered when the proboscis was retracted. When insects defecated during the act of feeding, the time for defecation was set to 0 (immediate defecation).

2. Voluntary fasting before and after ecdysis: For this observation, mice was offered daily (experiment was set as described in 1) during a period of $10 \mathrm{~min}$. The number of days that the insect refused a blood meal offer before and after moulting was registered.

3. Period of inter-moulting: The amount of days between ecdysis for every nymphal stage (N1 to N5) to imaginal emergence was registered in days.

4. Oviposition indices: Recently F1 emerged adults were paired in 16 couples in plastic containers (as described before for nymphs). There were observed the number of days required for female adults to oviposite (pre-oviposition period), the number of ovipositing females in the total of females (the oviposition index) and the number of eggs per female. Eggs were placed in individual containers for the observation of the number of days for $1^{\text {st }}$ instar nymphs to eclode (the incubation period) and the number of nymphs ecloded in the total of laid eggs (the egg viability).

5. Longevity: The life span in number of days for males and females was observed.

6. Mortality rate: The number of dead insects for each nymphal stage and the percentage from the total initial of specimens was counted.

\section{RESULTS}

1. Time elapsed for defecation after a blood meal and number of meals: Fifth stage nymphs defecated fastest after a blood meal, i.e., $71 \%$ of the specimens defecated within 30 " and only $3 \%$ defecated after 2'30". Adult females, N1 and adult males followed in fastest elapsed times for defecation $(69 \%, 62 \%$ and $50 \%$ within $30 \%$, respectively) (Fig. 1). As insects developed, an increase in blood meals offerings and acceptances were observed due to the increased period required for moulting in older nymphal stages. The rates between the mean number of accepted blood meals/mean number of offers remained the same $(0.5,0.6,0.6,0.6$ and 0.5 for $\mathrm{N} 1$ to $\mathrm{N} 5$ respectively) showing 


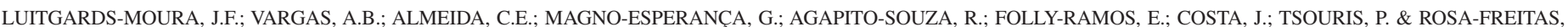

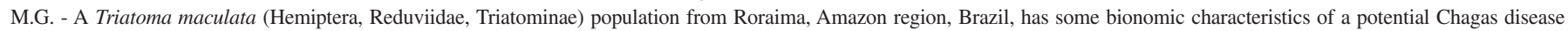
vector. Rev. Inst. Med. trop. S. Paulo, 47(3): 131-137, 2005.

Table 1

Inter-moulting duration periods and blood meals (offered and accepted) of Triatoma maculata during development

\begin{tabular}{|c|c|c|c|c|c|}
\hline \multirow{4}{*}{$\begin{array}{l}\text { Nymphal Stage } \\
\begin{array}{c}\text { N1 } \\
\mathrm{n}=39\end{array}\end{array}$} & \multicolumn{2}{|c|}{ Inter-moulting period } & \multicolumn{3}{|c|}{ Blood Meal* } \\
\hline & \multirow{3}{*}{$\frac{\text { Mean } \pm \text { SD(days })}{17.8 \pm 2.2}$} & \multirow{3}{*}{$\frac{(\text { Min.-Max.) }}{(17-24)}$} & \multicolumn{2}{|c|}{ Mean \pm SD } & \multirow{3}{*}{$\begin{array}{c}\text { (Min.-Max.) } \\
(2-3) \\
(1-2) \\
\end{array}$} \\
\hline & & & Offered & $2.1 \pm 0.3$ & \\
\hline & & & Accepted & $1.1 \pm 0.2$ & \\
\hline $\mathrm{N} 2$ & $20.8 \pm 14.6$ & $(15-100)$ & Offered & $2.9 \pm 2.1$ & $(1-14)$ \\
\hline $\mathrm{n}=35$ & & & Accepted & $1.7 \pm 1.5$ & $(1-9)$ \\
\hline N3 & $20.9 \pm 2.6$ & $(15-27)$ & Offered & $3 \pm 0.6$ & $(2-5)$ \\
\hline $\mathrm{n}=34$ & & & Accepted & $2.1 \pm 1.7$ & $(1-3)$ \\
\hline N4 & $24.9 \pm 6.1$ & $(19-44)$ & Offered & $3.7 \pm 0.9$ & $(3-6)$ \\
\hline $\mathrm{n}=34$ & & & Accepted & $2.1 \pm 0.6$ & $(1-4)$ \\
\hline N5 & $41.4 \pm 13.5$ & $(29-110)$ & Offered & $5.9 \pm 1.1$ & $(4-9)$ \\
\hline $\mathrm{n}=32$ & & & Accepted & $3.9 \pm 1$ & $(2-6)$ \\
\hline $\begin{array}{c}\text { Females } \\
\mathrm{n}=22\end{array}$ & $125.2 \pm 22$ & $(103-199)$ & Accepted & $9.8 \pm 6$ & $(3-3)$ \\
\hline $\begin{array}{l}\text { Males } \\
\mathrm{n}=10\end{array}$ & $122.1 \pm 14.8$ & $(102-164)$ & Accepted & $9.5 \pm 6$ & $(2-1)$ \\
\hline
\end{tabular}

*Mus musculus was offered weekly; SD - standard deviation; Min. - minimum, Max. - maximum, $\mathrm{n}=\mathrm{Nb}$. of specimens

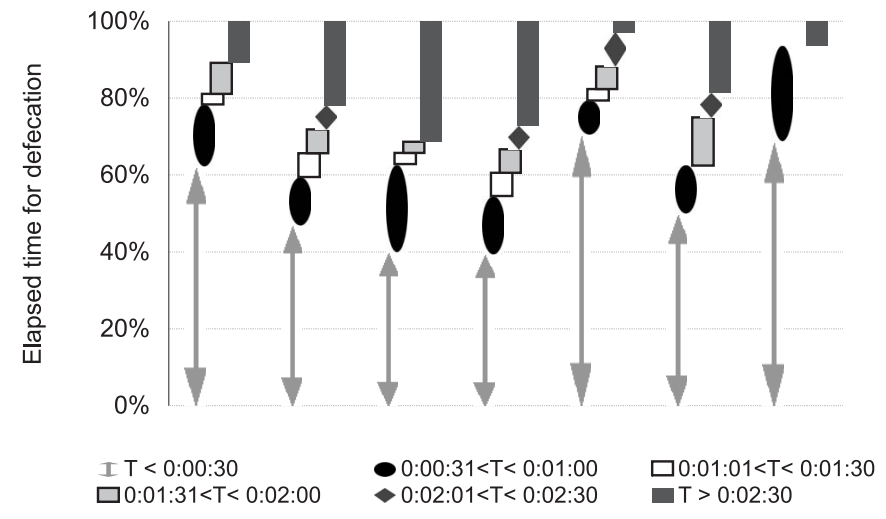

Fig. 1 - Elapsed time for defecation after a blood meal for nymphal stages and adults of Triatoma maculata.

one acceptance for every other offer (Table 1). An average of 10 meals was observed throughout nymphal stage (Table 1).

2. Voluntary fasting before and after ecdysis: Pos-ecdysis nymphs of all stages accepted a blood meal faster, taking 4.3 days mean to accept a meal while pre-ecdysis ones took 13 days mean (Table 2). The longest post-ecdyse fasting period was observed for adult females (7.4 days mean) and the shorter one for N4 (3 days mean). Pre-ecdysis N5 refused food for a longer period (17.6 days mean) while N2, N3 and $\mathrm{N} 4$ presented the shortest fasting period, around three days (Table 2). N1 displayed the shortest pre-ecdysis fasting period, 11.1 days mean (Table 2).

3. Period of inter-moulting: The total developmental period (egg to imaginal ecdysis) was approximately 120 days at room temperature (125.2 days mean for females and 122.1 for males) (Table 1). As the development advanced a higher number of days was necessary for moulting, 17.8 days between $\mathrm{N} 1$ and $\mathrm{N} 2$ while 41.4 days were required between N4-N5 (Table 1). During the 120 days required from N1 to imaginal emergence (that extended from November 24, 2000 to April 16, 2001), laboratory minimum and maximum temperatures were registered twice daily at 9:00h and at 15:00h. During N1 development minimum and maximum temperature means were $27.4^{\circ} \mathrm{C}$ and $28.7^{\circ} \mathrm{C}$, while for $\mathrm{N} 2$ it was $28.2^{\circ} \mathrm{C}$ and $30^{\circ} \mathrm{C}$, for $\mathrm{N} 3-28{ }^{\circ} \mathrm{C}$ and $29.9^{\circ} \mathrm{C}$, for $\mathrm{N} 4-28.5^{\circ} \mathrm{C}$ and $30.6{ }^{\circ} \mathrm{C}$ and for N5 $-28.3^{\circ} \mathrm{C}$ and $30.4{ }^{\circ} \mathrm{C}$.

4. Oviposition indices: Pre-oviposition period was 11.6 days mean for 16 females paired in couples. During a period that extended for a maximum of 272 days (229 days mean), those 16 females laid a total

\section{Table 2}

Voluntary fasting period before (pre-ecdysis) and after moulting (pos-ecdysis) in days for Triatoma maculata

\begin{tabular}{lccc}
\hline Stage & $\mathrm{n}$ & Mean $\pm \mathrm{SD}$ (days) & (Min.-Max.) \\
\hline Pos-eclosion egg-N1 & 39 & $6.4 \pm 1.6$ & $(6-13)$ \\
Pre-ecdysis N1-N2 & 39 & $11.1 \pm 0.3$ & $(11-12)$ \\
Pos-ecdysis N2 & 35 & $3.1 \pm 1.2$ & $(2-10)$ \\
Pre-ecdysis N2-N3 & 35 & $12.3 \pm 1.9$ & $(6-21)$ \\
Pos-ecdysis N3 & 34 & $3.1 \pm 2.5$ & $(1-9)$ \\
Pre-ecdysis N3-N4 & 34 & $12 \pm 2.2$ & $(7-18)$ \\
Pos-ecdysis N4 & 34 & $3 \pm 3$ & $(1-14)$ \\
Pre-ecdysis N4-N5 & 34 & $12.2 \pm 2.2$ & $(7-15)$ \\
Pos-ecdysis N5 & 32 & $5.8 \pm 3$ & $(1-15)$ \\
Pre-ecdysis N5-adult & 32 & $17.6 \pm 4.4$ & $(11-32)$ \\
Pos-ecdysis adult female & 22 & $7.4 \pm 2$ & $(16-18)$ \\
Pos-ecdysis adult male & 10 & $7.2 \pm 3$ & $(20-21)$ \\
\hline
\end{tabular}

$\mathrm{n}=\mathrm{Nb}$. of specimens 


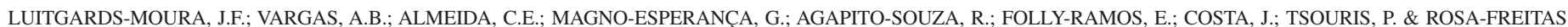
M.G. - A Triatoma maculata (Hemiptera, Reduviidae, Triatominae) population from Roraima, Amazon region, Brazil, has some bionomic characteristics of a potential Chagas disease vector. Rev. Inst. Med. trop. S. Paulo, 47(3): 131-137, 2005.

of 4091 eggs (a mean of 255.7 eggs/female), $72.8 \%$ of which viable. Room temperature was verified throughout the oviposition period in the morning and in the afternoon and daily averages were calculated. Egg incubation period varied from 14 to 42 days, depending on the temperature (- 0.98 correlation, i.e., the bigger the room temperature, the lower the incubation temperature, Fig. 2).

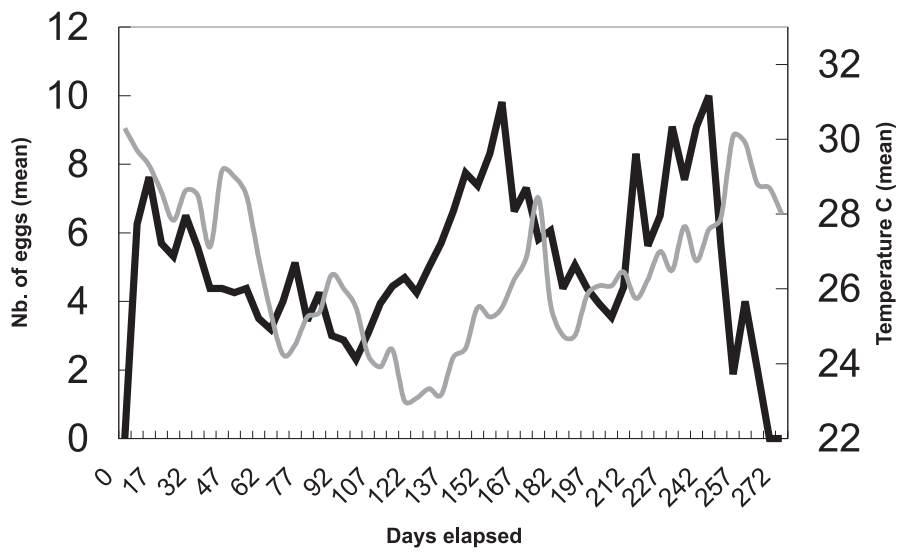

Fig. 2 - Number of eggs laid (mean) and room temperature values (mean) for Triatoma maculata.

5. Longevity: Maximum longevity was 373 for males (250 mean) and 289 for females (246 mean) (Table 3).

6. Mortality index: Thirty-four specimens reached adulthood (18 females and 16 males out of the initial forty N1 specimens). The
Table 3

Longevity, pre-oviposition period, number and viability of eggs laid for Triatoma maculata females

\begin{tabular}{llcc}
\hline & & Mean \pm SD & (Min.-Max.) \\
\hline Longevity (days) & Females & $246 \pm 4.9$ & $(197-289)$ \\
& Males & $250 \pm 6.9$ & $(155-373)$ \\
\hline Pre-oviposition period (days) & & $11.6 \pm 1.9$ & $(7-23)$ \\
\hline Nb. of eggs laid per female & & $255.7 \pm 6.9$ & $(183-327)$ \\
\hline Viability of eggs $(\%)$ & $72.8 \pm 3.9$ & $(38-96)$ \\
\hline
\end{tabular}

percentage of dead specimens at nymphal stage was $15 \%(\mathrm{n}=6$, two specimens at N1, three at $\mathrm{N} 2$ and one at $\mathrm{N} 3$ ).

\section{DISCUSSION AND CONCLUSION}

T. maculata, considered to be an ornithophilic species, readily accepted Mus musculus blood showing a post-ecdyse fasting period and developmental cycle that may indicate acceptance and easily metabolization of this blood source. Ornithophilism for some triatomines could be an opportunistic behaviour rather than a selective feature (DIOTAIUTI \& DIAS, 1987). The elapsed time between the end of the meal and defecation showed that T. maculata reached indices similar to other triatomine vector species such as Triatoma infestans, Triatoma brasiliensis, $P$. megistus, $R$. prolixus and Triatoma rubrovaria (Table 4).

Pos-ecdysis nymphs of all stages showed to be hungrier than pre-

Table 4

Nymphal stage period, number of eggs laid, blood source and temperature for Triatoma maculata and other closely related triatomine species

\begin{tabular}{|c|c|c|c|c|c|c|c|c|}
\hline Species & $\begin{array}{l}\text { Blood } \\
\text { source } \\
\text { in natura }\end{array}$ & $\begin{array}{l}\text { Geographical } \\
\text { origin }\end{array}$ & $\begin{array}{l}\text { Experimental } \\
\text { blood } \\
\text { source }\end{array}$ & $\begin{array}{l}\text { Blood } \\
\text { meals } \\
\text { (mean) }\end{array}$ & $\begin{array}{l}\text { Nymphal } \\
\text { duration } \\
\text { period (days) }\end{array}$ & $\begin{array}{l}\text { Nb. of } \\
\text { eggs } \\
\text { (mean) }\end{array}$ & $\begin{array}{l}\text { Temperature } \\
\text { (mean) }\end{array}$ & Reference \\
\hline T. maculata & Not verified & $\begin{array}{l}\text { Passarão, Roraima } \\
\text { State, Brazil }\end{array}$ & Mus musculus & 10.1 & $120^{3}$ & 256 & $27.4-28.7^{\circ} \mathrm{C}^{4}$ & This work \\
\hline T. maculata & Not cited & Not cited ${ }^{1}$ & Gallus gallus & Not cited & 160 & Not cited & $28^{\circ} \mathrm{C}$ & $\begin{array}{l}\text { Feliciangeli \& } \\
\text { Rabinovich } 1985, \\
\text { Espínola et al. } 1981\end{array}$ \\
\hline T. maculata & Birds & Not cited $^{2}$ & Gallus gallus & Not cited & 192 & Not cited & $25^{\circ} \mathrm{C}$ & Silva et al. 1995 \\
\hline T. maculata & Birds & Not cited ${ }^{2}$ & Gallus gallus & Not cited & 154 & Not cited & $30^{\circ} \mathrm{C}$ & Silva et al. 1995 \\
\hline T. pseudomaculata & $\begin{array}{l}\text { Chicken and } \\
\text { pigeons mainly }\end{array}$ & Not cited & Columba livia & 14.7 & 398 & 264 & $28^{\circ} \mathrm{C}$ & Gonçalves et al. 1997 \\
\hline T. brasiliensis & Rodents mainly & $\begin{array}{l}\text { Simplício Mendes, } \\
\text { Piauí State, Brazil }\end{array}$ & Mus musculus & 11 & 160 & 142 & $24{ }^{\circ} \mathrm{C}$ & Soares et al. 2000 \\
\hline T. infestans & Not cited & $\begin{array}{c}\text { Minas Gerais State, } \\
\text { Brazil }\end{array}$ & Gallus gallus & Not cited & $131-134$ & $649 \pm 123$ & $26-28^{\circ} \mathrm{C}$ & $\begin{array}{l}\text { Perlowagora- } \\
\text { Szumlewicz } 1969\end{array}$ \\
\hline T. rubrovaria & Rodents mainly & $\begin{array}{c}\text { Santana do Livramento, } \\
\text { Rio Grande do Sul } \\
\text { State, Brazil }\end{array}$ & Mus musculus & 11.1 & 180 & Not cited & $28^{\circ} \mathrm{C}$ & Almeida et al. 2003 \\
\hline
\end{tabular}

${ }^{1}$ Colony maintained for five years in the Insectary of the Division de Endemias Rurales, Venezuela; ${ }^{2}$ Colony from the Insectary of the Oswaldo Cruz InstituteFIOCRUZ, Rio de Janeiro, Brazil; ${ }^{3} 125.2$ for females and 122.1 for males; ${ }^{4}$ Room temperature (variable during the study, see text) 


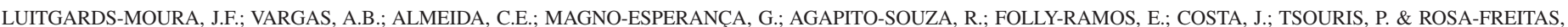

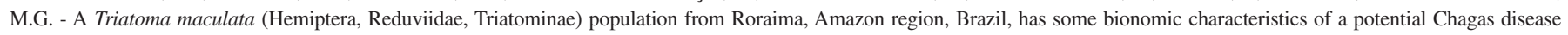
vector. Rev. Inst. Med. trop. S. Paulo, 47(3): 131-137, 2005.

ecdysis ones. Pos-ecdysis nymphs required 4.3 days mean to accept a blood meal while pre-ecdysis nymphs took 13 days mean to accept a meal (Table 2). Pre-ecdysis metabolism changes aiming storage and energy usage for moulting would be responsible for this figure (DIOTAIUTI \& DIAS, 1987). In addition, insects may have less appetite due to this energy storage (DIOTAIUTI \& DIAS, 1987). Thus, after moulting an increase in appetite would be expected due to the long period of fasting in pre-ecdysis.

The time for defecation is inversely proportional to the amount of blood ingested and positively proportional to elapsed fasting time and weight of the insect (TRUMPER \& GORLA, 1991). The amount of ingested blood and feeding frequency period are also density-dependent (TRUMPER \& GORLA, 1991). Being so, low-density triatomine populations may represent a higher transmission risk than high-density populations, a situation that may occur in infestation (e.g. colonization) and re-infestation (e.g. after insecticide spraying).

It has been shown that elapsed defecation time of more than one min following feeding correspond to a departing distance $>3 \mathrm{~cm}$ from the bite site, in most cases (ALMEIDA et al., 2003). T. cruzi transmission is therefore facilitated when a given species has the characteristic of defecating either during or less than one min after feeding (ALMEIDA et al., 2003). Most of the N5 defecations (71\%) occurred within 30" after the blood meal, demonstrating the importance of this behavior in T. maculata as a potential vector.

Inter-moulting and developmental time periods might be affected by temperature and blood source. Developmental period was approximately 120 days at a room temperature mean of $28.5^{\circ} \mathrm{C}$ for $T$. maculata fed on mice. Longer periods were observed for T. maculata using Gallus gallus as blood source, e.g., 154 days at $30{ }^{\circ} \mathrm{C}$ (SILVA et al., 1995), 160 days at $28^{\circ} \mathrm{C}$ (FELICIANGELI \& RABINOVICH, 1985; ESPÍNOLA et al., 1981) and up to 192 at $25^{\circ} \mathrm{C}$ (SILVA et al., 1995) (Table 4).

Pre-oviposition period for T. maculata was 11.6 days mean at 28 ${ }^{\circ} \mathrm{C}$. Similar results were found for $T$. infestans with 15 - 16 days mean (PERLOWAGORA-SZUMLEWICZ, 1969), T. brasiliensis with eight days mean at $30{ }^{\circ} \mathrm{C}$ (BRASILEIRO, 1982), T. rubrovaria with 15 days at $25^{\circ} \mathrm{C}$ and 13 days at $30^{\circ} \mathrm{C}$ (SILVA, 1985).

T. maculata laid an average of 256 eggs per female. Comparable results were found for $T$. brasiliensis and $T$. pseudomaculata that had 142 and 264 eggs/female, respectively (GONÇALVES et al., 1997; SOARES et al., 2000) (Table 4).

Hatching or egg incubation period varied from 14 - 42 days for $T$. maculata, accompanying temperature variation $\left(23.6-29.3{ }^{\circ} \mathrm{C},-0.98\right.$ correlation). Egg incubation period for T. maculata was previously observed to be 19 days mean (at $28{ }^{\circ} \mathrm{C}$, FELICIANGELI \& RABINOVICH, 1985), while T. pseudomaculata had 18 days (at 28 ${ }^{\circ} \mathrm{C}$, GONÇALVES et al. 1997) and T. infestans showed a period variation from 27 to 46 days (at $18.5-28.7^{\circ} \mathrm{C}$ range, HACK, 1955). T. infestans could initiate egg eclosion on day 11 after oviposition, although eclosion usually occurred between days 17 - 20 (at 24 to $28{ }^{\circ} \mathrm{C}$, PERLOWAGORA-SZUMLEWICZ, 1953).
Only around the week 28 after reaching the adulthood females start to die, decreasing oviposition. The longevity of the females was 246 days mean. During their lives, females presented 11.6 days mean pre-oviposition period. Females laid eggs continuously for 229 days mean, withhelding a fertility period of 241 days mean. Thus, it is estimated that females remain fertile until near to their death.

Older stages required more time to moult $(\mathrm{N} 1-\mathrm{N} 2=17.8$ days, $\mathrm{N} 4$ - N5 = 38.8 days average), with individual variations observed (N2 - N3 presented the biggest variances $=14.6$ days). However, because insects were kept at room temperature, environmental temperature changes verified during nymphal stages may have affected moulting period duration. Increase in temperatures within a certain limit, usually accelerated development (SILVA et al., 1995).

T. maculata specimens from Venezuela were found to have fed on bird blood (TONN et al., 1978). The ornitophilic behaviour of $T$. maculata was also observed in the present study, not only in Passarão, but also in a preliminary investigation in Normandia, Bonfim and Uiramutã Municipalities all in the Roraima savannah region, where many specimens were collected in the chicken houses. The use of mice as blood source may have shortened the development time duration for T. maculata. A closely related species, T. pseudomaculata is reported as having 240 days development approximately from egg to adult when pigeon was used as blood source (at $28^{\circ} \mathrm{C}$, GONÇALVES et al., 1997). This might demonstrate that the frequent verified association of $T$. maculata with birds is oportunistic rather than adaptative and that the biotic potential may be favored through a more frequent contact with mammal blood found in the peri- and intradomicile.

N5 were able to stay without food for longer periods (17.6 days) than the younger stages $(\mathrm{N} 1=11.1$ days $)$ even when a blood meal source was offered daily. This endurance characteristic and also the fact that females remain fertile until close to their death show the epidemiological importance of the T. maculata Passarão population. Also, only $15 \%$ of the nymphs died demonstrating the resistance of the species during nymphal period.

Triatoma maculata showed characteristics that could account the species as a potential $T$. cruzi vector. T. maculata nymphs fed frequently, defecated while still in the host, i.e. during feeding and immediately after proboscis retraction, were able to develop using mouse blood as food source, could fast and presented low mortality rates during nymphal stages. These results indicate $T$. maculata as a potential $T$. cruzi vector.

Aditional experiments should be conducted aiming the comparison using at least one alternative blood source (e.g. bird) for feeding, defecation, longevity and mortality rates for $T$. maculata specimens. Also, susceptibility infection experiments encompassing differentiation aspects should be carried out to corroborate T. maculata population of Passarão, Roraima, as a good vector for T. cruzi.

\section{CONCLUSIONS}

The Passarão population of T. maculata should be considered a potential vector of $T$. cruzi since it shows a capacity to infest artificial peri-domiciliary ecotopes as represented by the colonization of chicken 


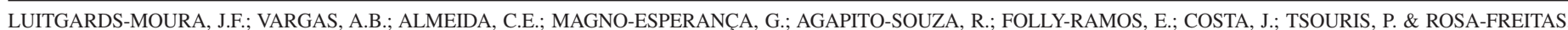
M.G. - A Triatoma maculata (Hemiptera, Reduviidae, Triatominae) population from Roraima, Amazon region, Brazil, has some bionomic characteristics of a potential Chagas disease vector. Rev. Inst. Med. trop. S. Paulo, 47(3): 131-137, 2005.

house annexes, to blood source eclecticism achieving full development in a different blood source from that used in the natural ecotopes, to defecate immediately after the blood meal while still in the host and to the fact that has been previously found naturally infected by T.cruzi The species shall be under constant entomological vigilance.

\section{RESUMO}

\section{Uma população de Triatoma maculata (Hemiptera, Reduviidae, Triatominae) proveniente de Roraima, Amazônia, Brasil, possui algumas características bionômicas de vetor potencial de doença de Chagas}

A doença de Chagas é de rara ocorrência na Região Amazônica Brasileira, onde contudo as condições para o estabelecimento de ciclos domésticos existem. Um estudo previamente realizado em áreas de colonização agrícola no Estado de Roraima, mostrou a possibilidade de ciclos autóctones de transmissão virem a ocorrer uma vez que todos os elementos estavam lá presentes, indivíduos infectados por Trypanosoma cruzi, espécies de triatomíneos anteriormente descritas como infectadas por T. cruzi na Região Amazônica de países fronteiriços e, ambientes domiciliares e peri-domiciliares favoráveis à colonização de triatomíneos. Triatoma maculata foi a espécie mais frequentemente encontrada, tendo sido coletada em galinheiros no peridomicílio e esporadicamente nos domicílios. Visando investigar a potencialidade de T. maculata como espécie vetora na área, algumas características bionômicas foram estudadas em condições de laboratório incluindo freqüência de alimentação, tempo de defecação pós-prandial, tempo de jejum voluntário na pré- e na pós-ecdise, período inter-mudas, períodos de pré-oviposição e de oviposição, índice de oviposição, período de incubação, viabilidade dos ovos, índices de longevidade e de mortalidade. Os resultados mostraram que a população de $T$. maculata da Colônia Agrícola do Passarão deve ser considerada vetora em potencial do T. cruzi uma vez que mostrou capacidade de infestar ecótopos artificiais no peridomicílio, de se alimentar com frequiência durante o período ninfal, de possuir um ciclo de desenvolvimento relativamente curto com 2,9 gerações/ano, de possuir hábitos ecléticos de alimentação, de defecar imediatamente após a hematofagia quando ainda no hospedeiro e devido ao fato de ter sido previamente encontrada infectada por T. cruzi.

\section{ACKNOWLEDGEMENTS}

To Fundação Nacional de Saúde-FUNASA, Secretaria do Estado de Saúde de Roraima-SESAU, Secretaria Municipal de Saúde-SEMSA, and Prefeitura de Boa Vista.

To Dr Terry V. Mc Intyre for assisting with English revision and critically reading the manuscript and to Museu de Ciências' staff for assisting with the experimental part of this work.

This study is part of the PhD thesis of José Francisco LuitgardsMoura. The work was supported by the Brazilian Council for Science and Development-CNPq (521176/ 98-0), the Oswaldo Cruz Institute FIOCRUZ, the Rio de Janeiro Research Foundation-FAPERJ and the Roraima Federal University-UFRR.

\section{REFERENCES}

1. ALMEIDA, C.E. - Triatoma rubrovaria (Blanchard, 1843) (Hemiptera - Reduviidae - Triatominae): estudos biológicos, ecológicos e isoenzimáticos associados à potencialidade vetorial no Rio Grande do Sul, Brasil. Rio de Janeiro, 2000. (Dissertação de Mestrado - Instituto Oswaldo Cruz).

2. ALMEIDA, C.E.; FRANCISCHETTI, C.N.; PACHECO, R.S. \& COSTA, J. - Triatoma rubrovaria (Blanchard, 1843) (Hemiptera-Reduviidae-Triatominae). III: Patterns of feeding, defecation and resistance to starvation. Mem. Inst. Oswaldo Cruz, 98: 367-371, 2003.

3. ALMEIDA, F.B. - Triatomíneos da Amazônia. Encontro de três espécies naturalmente infectadas por Trypanosoma cruzi no estado do Amazonas (Hemiptera: Reduviidae). Acta amaz. (Manaus), 1: 89-93, 1971.

4. BARRET, T.V. - Current research on Amazonian Triatominae. Mem. Inst. Oswaldo Cruz, 83(suppl. 1): 441-445, 1988.

5. BRASILEIRO, V.L.F. - Fecundidade e fertilidade da fêmea de Triatoma brasiliensis Neiva, 1911 (Hemiptera: Reduviidae). I. Influência da cópula e da longevidade. Rev. bras. Biol., 42: 1-13, 1982.

6. CARCAVALLO, R.U.; MARTINEZ-SILVA, R.; OTERO, M. \& TONN, R. - Infección natural de Rhodnius robustus Larrouse y Rhodnius pictipes Stål por T. cruzi y $T$. rangeli en Venezuela. Bol. Direcc. Malar., 15: 117-120, 1975.

7. COSTA, J.M. \& JURBERG, J. - Estudos bionômicos de Cavernicola lenti Barrett e Arias, 1985 (Hemiptera - Triatominae). Mem. Inst. Oswaldo Cruz, 85: 357-366, 1990.

8. COURA, J.R. - Doença de Chagas como endemia na Amazônia Brasileira: risco ou hipótese? Rev. Soc. bras. Med. trop., 23: 67-70, 1990.

9. COURA, J.R.; JUNQUEIRA, A.C.V.; BOIA, M.N. \& FERNANDES, O. - Chagas disease: from bush to huts and houses. Is it the case of the Brazilian Amazon? Mem. Inst. Oswaldo Cruz, 94(suppl. 1): 379-384, 1999.

10. COURA, J.R.; JUNQUEIRA, A.C.V.; GIORDANO, C.M. \& FUNATSU, R.K. - Chagas disease in the Brazilian Amazon. I. A short review. Rev. Inst. Med. trop. S. Paulo, 36: 363-368, 1994.

11. DIAS, E. - Doença de Chagas nas Américas. IV. Colômbia, Venezuela e Guianas. Rev. bras. Malar., 4: 255-280, 1952

12. DIAS, E. - Observações sobre eliminação de dejeções e tempo de sucção em alguns triatomíneos sul-americanos. Mem. Inst. Oswaldo Cruz, 54: 115-124, 1956.

13. DIAS, E. \& TORREALBA, J.F. - Breve nota acerca del Triatoma o Eutriatoma maculata Erichson (1848) Pinto 1931. Comprobación de su infestación en la naturaleza por Schizotrypanum cruzi. Gaceta med. (Caracas), 43: 377-379, 1936

14. DIOTAIUTI, L. \& DIAS, J.C.P. - Estudo comparativo do ciclo evolutivo de Rhodnius neglectus (Lent, 1954) alimentados em pombos ou camundongos. Rev. Soc. bras. Med. trop., 20: 95-99, 1987.

15. ESPÍNOLA, H.; RODRIGUEZ, F.; BERMUDEZ, M. \& TONN, R.J. - Informaciones sobre la biologia y el ciclo de vida de Triatoma maculata (Erichson, 1848) (Hemiptera, Reduviidae, Triatominae), en condiciones de laboratorio. Bol. Direcc. Malar., 21: 140-142, 1981.

16. FELICIANGELI, M.D. \& RABINOVICH, J. - Vital statistics of Triatominae (Hemiptera: Reduviidae) under laboratory conditions. II. Triatoma maculata. J. med. Entomol., 22: 43-48, 1985 .

17. GONÇALVES, T.C.M.; CUNHA, V.; OLIVEIRA, E. \& JURBERG, J. - Alguns aspectos da biologia de Triatoma pseudomaculata Corrêa \& Espínola, 1964, em condições de laboratório. Mem. Inst. Oswaldo Cruz, 92: 275-280, 1997. 


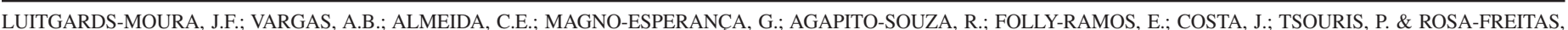

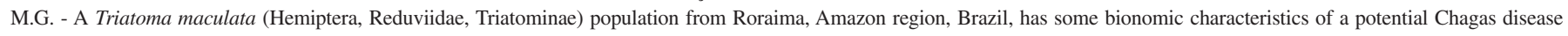
vector. Rev. Inst. Med. trop. S. Paulo, 47(3): 131-137, 2005.

18. HACK, W.H. - Estudios sobre biologia del Triatoma infestans (Klug 1834) (Hemiptera, Reduviidae). An. Inst. Med. reg., 4: 125-147, 1955.

19. LUITGARDS-MOURA, J.F. - Aspectos epidemiológicos da doença de Chagas em áreas de colonizaçao agrícola no estado de Roraima, Brasil. Rio de Janeiro, 2001. (Tese de Doutorado - Instituto Oswaldo Cruz).

20. LUITGARDS-MOURA, J.F.; BORGES-PEREIRA, J.; COSTA, J.; ZAUZA, P.L. \& ROSA-FREITAS, M.G. - On the possibility of autochthonous Chagas disease in Roraima, Amazon Region, Brazil, 2000-2001. Rev. Inst. Med. trop. S. Paulo, 47: 45-54, 2005.

21. MILES, M.A.; SOUZA, A.A. \& PÓVOA, M. - Chagas' disease in the Amazon Basin. III Ecotopes of ten triatomine bug species (Hemiptera: Reduviidae) from the vicinity of Belém, Pará State, Brazil. J. med. Entomol., 18: 266-278, 1981.

22. OTERO, M.A.; JIMENEZ, J.C.; CARCAVALLO, R.U.; ORTEGA, R. \& TONN, R.J. Actualización de la distribución geográfica de Triatominae (Hemiptera, Reduviidae) en Venezuela. Bol. Direcc. Malar., 15: 217-230, 1975.

23. PELlEGRINO, J. - Dados da doença de Chagas no estado de Minas Gerais. Hospital (Rio de J.), 41: 885-890, 1952.

24. PERLOWAGORA-SZUMLEWICZ, A. - Ciclo evolutivo do Triatoma infestans em condições de laboratório. Rev. bras. Malar., 5: 35-47, 1953.

25. PERLOWAGORA-SZUMLEWICZ, A. - A eficácia do expurgo domiciliário com hexaclorociclohexana no controle do vetor da doença de Chagas: a importância de alguns característicos biológicos dos triatomíneos no planejamento do ciclo e aplicação do inseticida. Rev. bras. Malar., 6: 63-100, 1954.

26. PERLOWAGORA-SZUMLEWICZ, A. - Estudos sobre a biologia do Triatoma infestans, o principal vetor da doença de Chagas no Brasil: importância de algumas de suas características biológicas no planejamento de esquemas de combate a esse vetor. Rev. bras. Malar., 21: 117-159, 1969

27. PESSOA, S.B. - Hemiptera-Triatomíneos e Cimicídeos. In: PESSOA, S.B. Parasitologia médica. Rio de Janeiro, Guanabara Koogan, 1988. p. 661-690.

28. PIFANO, C.F.R. - II. La dinámica epidemiológica de la Enfermedad de Chagas en el Valle de los Naranjos, estado de Carabobo, Venezuela. Arch. venez. Med. trop. Parasit. med., 5: 31-45, 1973.

29. RAFAEL, J.A. \& PY-DANIEL, V. - Maracá rainforest project: invertebrates \& Limnology, Preliminary report, INPA/RGS/SEMA. Entomology species list. In: RATTER J. A. \& MILLIKEN W., ed. London, 1989. p. 1-9.
30. SIFONTES, R. - Desarollo y estado actual del programa de control de la enfermedad de Chagas en Venezuela. IN: CONGRESO LATINOAMERICANO DE PARASITOLOGÍA, 4., San José, 1976. p. 79.

31. SILVA, I.G. - Influência da temperatura na biologia de triatomíneos. I. Triatoma rubrovaria (Blanchard, 1843) (Hemiptera, Reduviidae). Rev. goiana Med., 31: 1 37, 1985.

32. SILVA, I.G.; FERNANDES, F.F. \& SILVA, H.H.G. - Influência da temperatura na biologia de triatomíneos. XX. Triatoma maculata (Erichson, 1848) (Hemiptera, Reduviidae). Rev. Pat. trop., 24: 49-54, 1995.

33. SOARES, R.P.; GRAÇAS-EVANGELISTA, L.; LARANJA, L.S. \& DIOTAIUTI, L. Population dynamics and feeding behavior of Triatoma brasiliensis and Triatoma pseudomaculata, main vectors of Chagas disease in Northeastern Brazil. Mem. Inst. Oswaldo Cruz, 95: 151-155, 2000.

34. TONN, R.J.; CARCAVALlO, R.U.; ORTEGA, R. \& CARRASQUERO, B. - Métodos de estudio de triatóminos en el médio silvestre. Bol. Direcc. Malar., 16: 146-152, 1976.

35. TONN, R.J.; OTERO, M.A.; MORA, E.; ESPINOLA, H. \& CARCAVALLO, R.U. Aspectos biológicos, ecológicos y distribución geográfica de Triatoma maculata (Erichson, 1848) (Hemiptera, Reduviidae), en Venezuela. Bol. Direcc. Malar., 18 16-24, 1978.

36. TRUMPER, E.V. \& GORLA, D.E. - Density-dependent timing of defaecation by Triatoma infestans. Trans. roy. Soc. trop. Med. Hyg., 85: 800-802, 1991

37. VALENTE, S.A.S. \& VALENTE, V.C. - Situação atual da doença de Chagas na Amazônia Rev. Soc. bras. Med. trop., 26(supl. 2): 68-70, 1993.

38. VALENTE, S.A.S.; VALENTE, V.C. \& FRAHIA-NETO, H. - Considerations on the epidemiology and transmission of Chagas disease in the Brazilian Amazon. Mem. Inst. Oswaldo Cruz, 94(suppl. 1): 395-398, 1999.

39. WALSH, J.F.; MOLYNEUX, D.H. \& BIRLEY, M.H. - Deforestation: effects on vectorborne disease. Parasitology, 106(suppl.): 55-75, 1993.

40. WHO-WORLD HEALTH ORGANIZATION - Control of Chagas Disease. Wld. Hith Org. techn. Rep. Ser., (811), 2002.

41. ZELEDÓN, R. \& RABINOVICH, J.E. - Chagas' disease: an ecological appraisal with special emphasis on its insect vectors. Ann. Rev. Entomol., 26: 101-133, 1981.

Received: 25 November 2004

Accepted: 29 April 2005 